\title{
Pre-Service Teachers' Perceptions of Lecturers' Teaching and Learning Strategies in Moral Education
}

\author{
Charanjit Kaur Swaran Singh ${ }^{1, *}$, Tarsame Singh Masa Singh $^{2}{ }^{2}$ Eng Tek Ong ${ }^{3}$, Nadarajan Thambu $^{4}$, \\ Mohd Zailani Mohd Yusoff ${ }^{4}$, Sasigaran Moneyam ${ }^{5}$, Nadiah Yan Abdullah ${ }^{6}$ \\ ${ }^{1}$ Department of English Language \& Literature, Faculty of Language \& Communication, Universiti Pendidikan Sultan Idris, Malaysia \\ ${ }^{2}$ English Language Unit, Department of Language, Institute of Teacher Education, Tuanku Bainun Campus, Malaysia \\ ${ }^{3}$ Department of Educational Studies, Faculty of Human Development, Sultan Idris Education University, Malaysia \\ ${ }^{4}$ Faculty of Human Sciences, Sultan Idris Education University, Malaysia \\ ${ }^{5}$ School of Education and Modern Languages, UUM College of Arts and Sciences, Malaysia \\ ${ }^{6}$ Centre for Languages and General Studies, Universiti Pendidikan Sultan Idris, Malaysia
}

Received June 18, 2020; Revised September 20, 2020; Accepted October 15, 2020

\section{Cite This Paper in the following Citation Styles}

(a): [1] Charanjit Kaur Swaran Singh, Tarsame Singh Masa Singh, Eng Tek Ong, Nadarajan Thambu, Mohd Zailani Mohd Yusoff, Sasigaran Moneyam, Nadiah Yan Abdullah. "Pre-Service Teachers' Perceptions of Lecturers' Teaching and Learning Strategies in Moral Education," Universal Journal of Educational Research, Vol. 8, No. 11B, pp. 6307 6312, 2020. DOI: 10.13189/ujer.2020.082270.

(b): Charanjit Kaur Swaran Singh, Tarsame Singh Masa Singh, Eng Tek Ong, Nadarajan Thambu, Mohd Zailani Mohd Yusoff, Sasigaran Moneyam, Nadiah Yan Abdullah (2020). Pre-Service Teachers' Perceptions of Lecturers' Teaching and Learning Strategies in Moral Education. Universal Journal of Educational Research, 8(11B), 6307 - 6312. DOI: 10.13189/ujer.2020.082270.

Copyright $\bigcirc 2020$ by authors, all rights reserved. Authors agree that this article remains permanently open access under the terms of the Creative Commons Attribution License 4.0 International License

\begin{abstract}
Effective lecturers have a repertoire of effective practices to ensure student learning outcomes. This study investigates pre-service teachers' perceptions on moral lecturers' teaching and learning strategies at two different higher learning institutions. A descriptive case study design was employed in developing the study. Focus group interview was conducted with seven pre-service teachers on voluntary basis. Only one instrument was used in data collection namely focus group interview protocol. Thematic analysis was used to analyse the interview data. Six categories were analysed from the interview data: intellectual excitement, values, inquiry and reflection, technology integration and resources, constructive alignment and international and cultural diversity. The findings from the study revealed that the teaching and learning strategies incorporate 21 st century learning including getting pre-service teachers' engagement through technology use and multimedia resources.
\end{abstract}

Keywords Moral Education; Teaching and Learning Strategies; Pre-Service Teachers

\section{Introduction}

Accelerated change has transformed the nature of higher education today [1]. Students in higher education now demand more than classroom participation and this demand has shifted the mission of higher education specifically teaching and learning strategies. This indicates that more innovative pedagogical strategies are being pursued in realising a high-quality education. The demand for teaching effectiveness has increased; higher education today must shift away from traditional methods to embrace the student-centred approach given the demands of students with diversified background enrolling into higher education institutions.

\section{Literature Review}

[2] investigated how Islamic education teachers can influence students' morality. Developing students' morality is one of the characteristics stipulated in the Integrated Curriculum for Secondary Schools (ICSS) in Malaysia. The ICSS focuses on developing student 
potential in a holistic manner covering spiritual, intellectual, emotional and physical growth. The researchers collected data by interviewing two teachers teaching in the International Islamic School. Their findings revealed that students tended to be influenced negatively by their peers when they meet friends outside the school context. Also, parental roles have affected students' attitudes and moral behaviour. Their findings showed that teachers require assistance from the school stakeholders, parents and media to create awareness to infuse moral values among students. Nevertheless, moral education upholds the traditional goal of education because society cannot rely solely on schools to produce intelligent students; their attitudes and behaviour should be nurtured together. [3] divulged that schools play an important role in influencing students' thinking and feeling and in guiding students to make decisions on right and wrong.

[4] proposed five moral values specifically to signify moral values for teaching purpose in the classroom. The first one refers to value transfer or moral educational transfer. It is about individuals with good attitudes who can sustain good behaviour of individual students. The teachers' role is to guide the students to have an open mind to deal with multicultural and changing society with varied religions. The second value is reflective practitioner. This refers to how teachers can model and teach the students to reflect the moral values through action. The teachers' action could influence students in thinking about how their responsibility would affect their behaviour. The third moral value is Moral Sensitivity. This deals with teachers discussing selected issues, views, conflicts and practices. Teachers can create a dialogue session to elicit student feedback concerning moral reasoning on selected sensitive issues if the need to discuss moral values arises. The fourth moral value is participation and dialogue. These take place when teachers ask students to take part in dialogic activities that would require students to reconstruct and challenge their views. The teachers take the facilitator role hence allowing students to relate between dialogic activity and action through classroom discussion and participation. The fifth moral value is moral politics that is implanted in a political context. It takes the role of education in political action for social change. Teachers can do this through their teaching to modify the world and in teaching for social justice. According to $[5,2]$, teachers plays a crucial role in valuing and fostering students' moral personality, character and behaviour.

Islamic education teachers also play equal roles as the moral education teachers to nurture good qualities in students' behaviour and personality. Both the Islamic education teachers and moral education teachers faced some problems and challenges in nurturing students' moral values [2]. Some researchers agree that the views supporting offending behaviour are not solely because of one factor. [6] divulges that four main factors contribute to the decline in students' moral values namely students' attitudes, peer influence, parents' attitudes and social surroundings and mass media influence.

\section{Methodology}

This research uses qualitative method because the main intention of the study is to explain and explore very rich information about focus of the research. As [7] pointed out, "qualitative methods typically produce a wealth of detailed information about a much smaller number of people and cases." The aim of this study was to investigate pre-service teachers' perceptions of lecturers' teaching and learning strategies in Moral Education. The interview technique was used in data collection. The participants in this study were seven pre-service teachers enrolled in Moral Education studies from two different public universities in Malaysia. The undergraduates were in their fourth semester of study and participated voluntarily; focus group interviews were conducted with the seven students to collect a variety of information. Data from the focus group interviews were analysed using thematic analysis to uncover the pre-service teachers' perceptions of lecturers' teaching and learning strategies in Moral Education. The suggestions given by the pre-service teachers to improve the teaching and learning strategies were also recorded.

\section{Findings}

The interview protocol comprised of instruction notes to guide the researchers in obtaining information about the Moral course and aspects of teaching and learning including intellectual excitement, values, inquiry and reflection, technology integration and resources, constructive alignment and international and cultural diversity.

Based on the focus group interview conducted, during the session on intellectual excitement, pre-service teachers shared that the moral lesson conducted by their lecturers is interesting. Intellectual excitement refers to students being actively engaged in the process and content of learning to the point that they are intellectually stimulated and challenged, intrinsically motivated and find learning to be personally meaningful. Intellectual excitement is probably the most powerful motivating force for students and teachers alike According to the students, the moral lesson is interesting because it is related to social issues involving communities. Not only that, the moral lesson topics discussed were closely related to their daily lives, their own life experiences and that of others in the classroom. The students revealed that the real-life examples were shared by them and also by their lecturers. According to [8], moral values play an important role in human life as they embody what occur in life individually or collectively.

Students divulged that the moral lesson is easy because 
they have this conception that moral lesson would be easy if viewed in a positive way. Students added that the moral lesson is fun because the course has embedded activities such as moral exhibition on moral issues, and presentation on moral lesson from local and foreign sources. This is further supported by the other students who mentioned that the moral lesson is fun because they get criticisms from peers during presentation and elaborations on peers' opinions. When probed further on what was meant by fun, they then shared that fun learning included a visit to an old folk's home, forum activity online and debate among the students. Students were also excited upon discussing ontology theory. They shared an example of the Robin Hood attitude of those who steal from the rich to help the poor. The discussion on Robin Hood's issue was very provocative because they evaluated whether it was right or wrong for Robin Hood to do that. The debate upon accepting Robin Hood's action was being argued based on morality. Morality is interpreted as being good and bad built on a certain set of norms and principles [8]. This is supported by [3] who adds that morality can be clustered into respect, responsibility, integrity, and honesty [3].

The issue of Robin Hood and his actions raised issues concerning integrity. The students were able to justify Robin Hood's issue in relation to morality. They could relate Robin Hood's issue to social situations as they activated their higher order skills namely problem solving, reasoning and inferring to familiarise with issues in society. [4] shares that "values are tied closely in the curriculum, the school ethos and the behaviour of the teacher". In the discussion on Robin Hood, lecturer's efficiency in teaching the moral course explicitly is necessary but the students have to master the underlying moral principles experientially so that they can practice the values learnt in the classroom. Generally, moral values are viewed as concealed aspect as they mirror abstract fundamentals including respect, integrity, honesty, justice, and so forth. The lecturers can assess students' mastery of these abstract elements by relating to students' personal life experiences $[9,10,28]$.

When the lecturers attempt to probe or situate the abstract elements, deliberately it will have some impact on students' critical thinking. According to [4], it is very important for students to internalise moral values as this would influence their thinking. This is further supported by [11] on the importance of exploring moral values in students' life. Moral values can be implanted in students as the lecturers try suitable strategies to teach the students specifically about morality. Very often, society blames the lecturers, teachers or parents if the students misbehave, for example, refuse to show respect to elders or tell lies [8]. Nevertheless, students always emulate their lecturers in the university so that they can be good and successful individuals just like their lecturers. Students view lecturers as their mentors and lecturers' behaviour and attitudes can influence the students' actions because these students would like to emulate their lecturers $[12,13,14]$. Subsequently, the lecturers should present themselves as role models for their students.

Based on the focus group interview conducted relating to the discussion on the importance of quality learning space, the students shared that their university is well-equipped with technology in the classroom. The quality teaching and learning spaces encourage and allow a wide range of teaching and learning methods. The students divulged that their lecturers used multimedia to prepare the PowerPoint slides for lectures. Students mentioned that they are aware of their lecturer's teaching strategies that emphasise 21st century learning. Besides that, students said that a conducive learning environment is crucial for successful learning. They shared that their lecture halls are equipped with air conditioner, LCD and internet access; they said their lecturers always remind them to get the recommended compulsory books and other resources from the library. The students further shared that the lecturers' strategy of using multimedia was very effective because the multimedia serves as a medium to facilitate learning including for those students with special needs. Students said that their lecturers provide equal opportunity to practice the skills obtained and learned based on real-life experiences designed for them before they could be exposed to the actual assessment to test their ability so that they can implement the acquired skills. Effective teaching and classroom organisation lead to better student outcomes. Teaching and learning activities are carried out through electronic media in which lecturers use information and communications technology (ICT) as the main source to impart knowledge. This is supported by [15] that ICT has actually facilitated student learning by helping students to move from teacher-centred to student-centred forms of delivery [29]. [16] opined that developments in ICT have impacted delivery of teaching and learning at the higher learning institutions. $[17,18]$ agree that ICT developments have contributed significantly to lifelong learning. A study conducted by [19] to investigate the relationship between relationship between interpersonal communication competence skills (ICC) skills and digital citizenship among pre-service teachers revealed that these skills crucial to mediate behaviour for practical purposes. Good mastery of the ICC skills can assist pre-service teachers to develop the necessary skills and knowledge to facilitate learning.

From the interview conducted with the students in relation to constructive alignment, students shared that their lecturers related theories with real life situations. Constructive alignment refers to developing the knowledge base and student learning outcomes. It is a balancing between all the elements in teaching and learning for actual practice. Students are always given the chance to share their real-life experiences with one another in the classroom. This is supported by [20] on the importance of allowing students to master values clarification and apply 
them during classroom discussion.

In terms of nurturing good values related to students' values and beliefs which have a critical impact on decision making, students shared that their lecturers always provide them an opportunity to test their critical and creative thinking skills and problem solving $[21,22,30]$. They do so through the activities or situations assigned by their lecturers. Furthermore, the students mentioned the importance of teamwork spirit, group work, lifelong learning and entrepreneurship. One of them mentioned that he took the initiative to venture into a small business whereby he sold budget meals for RM3 each. The student shared that at first it was very challenging but with the help and cooperation from his peers, he learnt that he could actually set up the business with his other friends who were willing to collaborate. They were taught time management skills and referred to two-way communication skills between lecturers and students. The student shared that they explored and experienced these skills when they were out for the teaching practice (micro teaching). Not only that, they were exposed to action research skills, lifelong learning and also emotion control. Their experience undertaking the moral course has actually taught them to love each other, share food and always check on their friends by asking if they have any problems. These findings are in line with [4] as it is very important for the lecturers to infuse moral values through teaching in the classrooms. The act of transferring the moral values can be carried out by being a good role model for students. Lecturers can always show students how to be tolerant and flexible individuals by having an open mind and being ready to accept friends in the class.

As for the internationally and culturally diverse learning environment, it refers to the teaching and learning activities for teachers to manage educational processes. Students shared that they were not given opportunity to collaborate with international students but they read international reviews for their assignments. This is supported by findings from [23] study on the importance of debate-based ethics education to promote ability and moral judgment among students.

As for the climate of inquiry, this refers to the process to develop the environment of lifelong practices of self-discipline [24]. The students stated that their assignments require them to find a moral lesson from other countries and they have to conduct a presentation based on their findings. The students have to find sources of the lesson plans from New Zealand, Great Britain and Singapore. Also, the assignment tasks given to the students require them to activate their critical and creative thinking skills as they have to think about and answer many questions related to the assignments given [25]. The students shared that their lecturers are very kind as they become their counsellors to discuss financial or family problems. The students expressed that they can share most of their problems with their lecturers. On a final note, the students mentioned that they would prefer to have community service and topical seminar on moral education to be embedded into their moral course.

Some other related findings were also reported. Students suggested that the lecturers should also prioritise them by spending some time. In other words, students prefer lecturers who are able to create a caring learning environment which is crucial towards developing positive relationship and effective learning [28]. Students shared that they preferred if the lecturers can ask for their opinions during lectures to build rapport so that they can easily connect with them. The students also requested to have fieldwork activities and more exposure for practicum to gain information from the community. They mentioned that they would like to transform the assignments prepared for presentation to be shared with the communities rather than reading. They expressed that the lecturers should not solely depend on the PowerPoint presentation but they can be creative by incorporating more group discussion, using videos and animation. The findings of this study are in line with [26]. Based on their case-study research on social competence, findings showed that teachers usually guide students to take part in group work. Students' collaboration in group work has the potential to produce quality work. Assignments given to the students would create a sense of greater accountability and strengthen their communication skills. The end results would reflect the learning process to enhance effective and meaningful communication among the students.

\section{Conclusions}

The students' interview analysis revealed that they wanted a more structured guidance from their lecturers in terms of good presentation and classroom management skills, effectiveness in facilitating students in completing coursework and assignment, nurturing personal qualities, and build good rapport with students. Students divulged that they need more activities allowing the opportunity to talk and listen, read, write and reflect about the course content through problem-solving exercises, informal small groups, and other activities which require students to apply what they are learning. Students must be given a chance to talk about what they are learning and what they have learnt, write about it, relate it to past experience and apply it in their daily life context. It is recommended that lecturers should integrate active learning strategies in the future namely question and answer, cooperative learning, collaborative learning, class discussions and problem solving. The lecturer role is as a facilitator rather than a knowledge source. In delivering curriculum in higher learning institutes in Malaysia, using active learning techniques and student-centred teaching strategies and role of lecturers as facilitators are emphasised in the syllabuses of all subjects specified by the Teacher Education Division, 
Ministry of Education [27].

\section{Acknowledgments}

We would like to acknowledge and thank the Research Management and Innovation Centre (RMIC) of Sultan Idris Education University for providing us with the NRGS Action Research Project Grant (Coded: 2018-0200-106-82). This NRGS (Niche Research Grant Scheme) Action Research Project Grant subsumes under a wider research grant, namely the NRGS (Coded: 2014-0001-107-82-2) entitled "Developing and Validating a Teaching and Learning Framework for Preparing Quality Teachers for the Future", of which the funding comes from the Higher Education Department, Ministry of Education, Malaysia. Equally, we would like to thank the participating pre-service teachers who were truly cooperative and marvelous.

\section{REFERENCES}

[1] Biggs, J., \& Tang, C. (2011). Teaching for quality learning at university (4th ed.). Maidenhead: McGraw-Hill/Open University Press/Society for Research into Higher Education.

[2] Adam, A. M. L., \& Hussien, S. (2018). The Role of Islamic Education Teacher in Moral Education: A Case Study of (IIS) Malaysia. Journal of Education and Practice, 9(36), $170-174$

[3] Kaur, S. (2015). Moral values in education. IOSR Journal of Humanities and Social Science, 20(3).

[4] Veugelers, W. (2008). Moral values in teacher education. In First Symposium on Moral and Democratic Education in Florina. Amsterdam, The Netherlands: University of Amsterdam.

[5] Tamuri, A. H. (2007). Islamic Education teachers' perceptions of the teaching of akhlaq in Malaysian secondary schools. Journal of Moral Education, 36:3, 371-386.

[6] Mardzelah Makhsin (Ed.) (2003). Teacher Education Series: Islamic Education. Kuala Lumpur, Malaysia: PTS.

[7] Patton, M. Q. (1990). Qualitative evaluation and research methods (2nd ed.). Thousand Oaks, CA: SAGE.

[8] Widya, G. M. (2017). Techniques for teaching Speaking Skill in Widya Gama Mahakam University. Journal of Linguistic and English Teaching, 2(1).

[9] Singh, C. K. S., Othman Lebar, Napisah Kepol, Rafiah Abdul Rahman, \& Kurotol Aini Muhammad Mukhtar. (2017). An Observation Of Classroom Assessment Practices Among Lecturers In Selected Malaysian Higher Learning Institutions. Malaysian Journal of Learning and Instruction, 14(1), 23-61.

[10] Singh, C. K. S., \& Samad, A. A. (2013). Portfolio as an assessment tool and its implementation in Malaysian ESL classrooms: A study in two secondary schools. Pertanika Journal of Social Science and Humanities, 21, 1255-1273.

[11] Roy, S. (2013). Importance of Moral Values in Student Life. Retrieved from http://www.importantindia.com/6898/importance-of-moral -values-in-student-life/

[12] Joseph, P. B., \& Efron, S. (2005). Seven worlds of Moral Education. Phi Delta Kappan, 86(7), 525-533.

[13] Ornstein, A. C., \& Hunkins, F. P. (1998). Curriculum: Foundations, principles, and issues (3rd ed.). Boston, MA: Allyn and Bacon.

[14] Pajares, M. F. (1992). Teachers' Beliefs and Educational Research: Cleaning Up A Messy Construct. Review of Educational Research, 62(3), 307-332.

[15] Stošić, L. The Importance of Educational Technology in Teaching. International Journal of Cognitive Research in Science, Engineering and Education Vol. 3(1), 111-114.

[16] Norazah, M. N., Mohamed Amin, E., \& Zaidan, A. B. (2011). Integration of e-learning in Teaching \& Learning in Malaysia Higher Education Institutions. In M. A. Embi (Ed.), e-Learning in Malaysian higher education institutions: Status, trend \& challenges (pp. 81-98). Malaysia: Ministry of Higher Education.

[17] Selvaraj, B. (2010). English Language Teaching (ELT): Curriculum reforms in Malaysia. Voice of Academia, 5(1), 51-60.

[18] Hashim, H, U., Yunus, M. M., Hashim, H., Norman, H \& Singh, C. K. S. (2019)."VLOG": An Innovation in Collaborative ESL Learning. International Journal of Innovation, Creativity and Change, 7(10), 261-276.

[19] Shun Xu, Harrison H. Yang, Jason MacLeod \& Sha Zhu (2019) Interpersonal communication competence and digital citizenship among pre-service teachers in China's teacher preparation programs, Journal of Moral Education, 48:2, 179-198, DOI: 10.1080/03057240.2018.1458605

[20] Lisievicia, P., \& Andronie, M. (2016). Teachers assessing the effectiveness of values clarification techniques in moral education. Procedia - Social and Behavioral Sciences, $400-$ 406.

[21] Singh, C. K. S., Singh, T. S. S., Ja'afar, H., Tek, O. E., Kaur, H., Moastafa, N. A., \&Yunus, M. (2020). Teaching Strategies to Develop Higher Order Thinking Skills in English Literature. International Journal of Innovation, Creativity and Change, 11(80), 211-231.

[22] Pillay, L. A. M., Singh, C. K. S., \& Yunus, M. M. (2020). Hots for Teaching and Learning in a Teacher Education University. International Journal of Psychosocial Rehabilitation, 23(4), 347-363.

[23] Wol-Ju Kim., \& Jin-Hee Park. (2019). The effects of debate-based ethics education on the moral sensitivity and judgment of nursing students: A quasi-experimental study. Nurse Education Today, 83, 104-200.

[24] Sukadaria, Prihonob, E. W., Singh, C. K. S., Syahruzahd, J. K., \& Wue, M. (2020). The Implementation of Character Education through Local Wisdom Based Learning. International Journal of Innovation, Creativity and Change, 
11(4), 389-403.

[25] Alaa, M., Albakri, I. S. M., Singh, C. K. S., Hammed, H., Zaidan, A. A., Zaidan, A. A., Albahri, O. S., Alsalem, M. A., Salih, M. M., Almahdi, E. M., Baqer, M. J., Jalood, N. S., Nidhal, S., Shareef, A. H., \& Jasim, A, N. (2019). Assessment and Ranking Framework for the English Skills of Pre-Service Teachers Based on Fuzzy Delphi and TOPSIS Methods. IEEE Access, vol. 7, pp. 126201-126223, 2019, doi: 10.1109/ACCESS.2019.2936898.

[26] Ten Dam, G. T. M. and Volman, M. L. L. (2003) A life jacket or an art of living: inequality in social competence education. Curriculum Inquiry, 33 (2) 117-137.

[27] Ministry of Education Malaysia. (MoE) (2014). Malaysia Education Blueprint Annual Report 2014. Kuala Lumpur.
[28] A. K. W. Gui , Maizura Yasin , Nur Surayyah Madhubala Abdullah , Norzihani Saharuddin (2020). Roles of Teacher and Challenges in Developing Students' Morality. Universal Journal of Educational Research, 8(3C), 52 - 59. DOI: $10.13189 /$ ujer.2020.081606.

[29] Norzihani Saharuddin , Suhailah Hussein , Nur Surayyah Madhubala Abdullah, Maizura Yasin (2020). Narrative as an Approach in Teacher Preparation Programme. Universal Journal of Educational Research, 8(3C), 31 - 43. DOI: 10.13189/ujer.2020.081604.

[30] Singh, C. K.S., Singh, T. S. M., Abdullah, N. Y, Moneyam, S., Ismail, M. R., Tek, O. E., Karupayah, T., Chenderan, K., Singh, M. K. R., \& Singh, J. K. S. RETHINKING ENGLISH LANGUAGE TEACHING THROUGH TELEGRAM, WHATSAPP, GOOGLE CLASSROOM AND ZOOM. Sys Rev Pharm 2020; 11(11):45-54. 